\title{
Factors associated to potential drug interactions in one Intensive Care Unit: a cross-sectional study
}

\author{
Fatores associados a interações medicamentosas potenciais em um Centro de Terapia Intensiva: estudo \\ transversal
}

\section{Factores asociados a interacciones medicamentosas potenciales en un Centro de Terapia Intensiva:}

Ana Laura Biral Cortes ${ }^{1}$ [C Zenith Rosa Silvino ${ }^{1}$

1. Universidade Federal Fluminense. Niterói, RJ, Brasil
Corresponding author Ana Laura Biral Cortes. E-mail: analaurabiral@yahoo.com.br.

Submitted on $11 / 07 / 2018$.

Accepted on 03/27/2019.

DOI: 10.1590/2177-9465-EAN-2018-0326

\section{Abstract}

Objective: to identify the factors associated to Potential Drug Interactions with High Alert Medications in the Intensive Care Unit of a Sentinel Hospital. Methods: a cross-sectional, retrospective study using a quantitative approach carried out at a Sentine Hospital in Rio de Janeiro. The research was based on the analysis of the prescriptions of patients hospitalized in the Intensive Care Unit of the Hospital, in a period of one year, in order to identify the drug interactions related to high alert medications in these prescriptions. Results: Of the 60 prescriptions analyzed, 244 were selected. In these prescriptions, 846 potential drug interactions related to high alert medications and 33 high alert medications were identified. Of the 112 types of potential drug interactions identified, some were more recurrent: tramadol e ondansetron, midazolam and omeprazole, regular insulin and hydrocortisone, fentanyl and midazolam, and regular insulin and noradrenaline. The variables polypharmacy, length of hospital stay, and some specific medications were associated with drug interactions with high alert medications. Conclusion and implications for practice: It is important to strengthen strategies to reduce adverse drug events. Therefore, the relevance of studies that investigate the origin of these events is highlighted. Drug interactions can represent medication errors. It's indispensable to work with strategies to better manage the medication system.

Keywords: Drug Interactions; Patient Safety; Safety Management; Intensive Care Units.

\section{Resumo}

Objetivo: Identificar os fatores associados às Interações Medicamentosas Potenciais com Medicamentos de alta vigilância em Centro de Terapia Intensiva de um Hospital Sentinela. Métodos: Estudo transversal, retrospectivo, de abordagem quantitativa, realizado em um hospital sentinela no Rio de Janeiro. A pesquisa apoiou-se na análise das prescrições de pacientes internados no setor, com recorte temporal de 1 ano, a fim de identificar as interações medicamentosas relacionadas a medicamentos de alta vigilância recorrentes nas mesmas. Resultados: Dos 60 prontuários analisados, selecionaram-se 244 prescrições. Nelas identificaram-se 846 interações medicamentosas potenciais, relacionadas aos medicamentos de alta vigilância e 33 medicamentos de alta vigilância. Dos 112 pares de interações identificadas, foram mais recorrentes: tramadol e ondansetrona midazolam e omeprazol, insulina regular e hidrocortisona, fentanil e midazolam, e insulina regular e noradrenalina. As variáveis polifarmácia, tempo de internação e alguns medicamentos específicos foram associadas às interações com medicamentos de alta vigilância. Conclusão e implicações para a prática: É importante fortalecer as estratégias para reduzir os eventos adversos relacionados a medicamentos. Portanto, destaca-se a relevância de estudos que levantem a natureza desses eventos. As interações medicamentosas podem configurar erros de medicação. Portanto, é indispensável que se trabalhe com estratégias para melhor manejar o sistema de medicação.

Palavras-chave: Interações medicamentosas; Segurança do paciente; Gestão da segurança; Unidades de Terapia Intensiva.

\section{Resumen}

Objetivo: identificar los puntos asociados a las Interacciones Medicamentos Potenciales con Medicamentos de alta vigilancia en un Centro de Cuidados Intensivos de un Hospital de Guardia. Métodos: estudio transversal, retrospectivo, de abordaje cuantitativo, realizado en un hospital de guardia en Rio de Janeiro. Esta investigación se basó en el análisis de las prescripciones medicamentosas de pacientes internados en un Centro de Cuidados Intensivos de un hospital, en un período de 1 año, con el objetivo de identificar las interacciones medicamentosas relacionadas con Medicamentos de alta Vigilancia recurrentes en las mismas. Resultados: de los informes analizados, se seleccionaron 244 prescripciones medicamentosas. En las 244 prescripciones de medicamentos, se pudieron identificar 846 Interacciones de Medicamentos Potenciales (IMP) relacionados a Medicamentos de Alta Vigilancia y 33 Medicamentos de Alta Vigilancia. De los 112 tipos de interacciones de medicamentos potenciales identificados, algunos han sido más recurrentes; a saber: tramadol y ondansetrón, midazolam y omeprazol, insulina regular e hidrocortisona, fentanilo y midazolam, insulina regular y noradrenalina. Las variables polifarmacia, tiempo de internación y algunos medicamentos específicos se asociaron a las interacciones medicamentosas potenciales con Medicamentos de Alta Vigilancia. Conclusión e implicaciones para la práctica: es importante fortalecer las estrategias para reducir los eventos adversos relacionados con medicamentos. Por lo tanto, se destaca la relevancia de los estudios que plantean la naturaleza de estos eventos. Las interacciones medicamentosas pueden provocar errores de medicación. Es imprescindible trabajar con estrategias para administrar mejor el sistema de medicación.

Palabras clave: Interacciones Medicamentosas, Seguridad del Paciente; Gestión de la Seguridad; Unidades de Cuidados Intensivos 


\section{INTRODUCTION}

Health care contributes greatly to human health, wellness, and longevity. However, these cares have always been, and still are, a risky enterprise. Both modern therapies, complex diagnoses and interventions, and the most basic care have been causing damage to patients. ${ }^{1}$

Drug therapy is the most widely used alternative and represents a major advance in the prevention and treatment of diseases. However, unnecessary or incorrect use of medications can trigger or aggravate morbidities, compromising users' quality of life or even causing death, being the drug-related morbidities currently considered a public health problem. ${ }^{2}$

There are different types of problems associated with medications, some are preventable and some are not. In the same way they may or may not result in damage. The definition of a WHO Expert Committee on Safety and Quality of Health Care states that: an adverse drug event is any harm that has occurred to the patient during drug therapy and resulting from appropriate care or undue or suboptimal care. Adverse events include: adverse reaction to a drug during its normal use and any secondary damage to a medication error. . $^{3,4}$

In this context, it is important to recognize the participation of drug interactions (DI). Although the simultaneous use of some drugs often increases therapeutic efficacy, certain combinations cause damage and may increase the risk of drug interactions. ADE accounts for approximately $5 \%$ of hospitalizations, of which 0.25 to $25 \%$ are due to drug interactions. ${ }^{5}$

Although often unidentified, the interactions are vertiginously present, especially in the hospital reality. In a multicenter study, it was observed that in the first 24 hours of hospitalization in Intensive Care Units, $70.6 \%$ of the patients presented at least one drug interaction. The total number of drug interactions was 2,299, with 350 types of drug ${ }^{6}$

Therefore, Dls can cause damage and be classified as adverse drug events (ADE). According to the Health Surveillance Notification System (NOTIVISA - "Sistema de Notificações em Vigilância Sanitária" in Portuguese language) of the National Health Surveillance Agency (ANVISA - "Agência Nacional de Vigilância Sanitária" in Portuguese language), a total of 103,887 adverse events were registered in Brazil between 2006 and 2013 , of which 38,730 were related to drugs. ${ }^{7,8} \mid \mathrm{t}$ is also estimated that adverse events resulting from medication errors are one of the most frequent patient safety problems in clinical settings. ${ }^{9}$

In this sense, authorities have established drugs that should be greater controlled, since they are associated with more representative damages to the patient. High Alert Medications (HAMs) or Potentially Hazardous Drugs (PHDs) have a high risk of causing significant harm when mistakenly used. ${ }^{10}$ Although the errors are not necessarily more common with these medications, the consequences of an error are clearly more serious for the patients.

In addition to being harmful to patients, ADEs increase the costs related to health care. In a study carried out in Brazil, in the hospital setting, the costs related to ADEs, calculated in 6 months of analysis, were $R \$ 96,877.90$. Direct costs totaled $R \$ 26,463.90$, of which $R \$ 20,430.36$ were obtained from the hospital and $\mathrm{R} \$ 6,033.54$ from the perspective of the Unified Health System (SUS - "Sistema Único de Saúde" in Portuguese language). Of this amount, $R \$ 14,380.13$ were due to non-preventable ADEs and $\mathrm{R} \$ 12,083.77$ due to preventable ADEs. ${ }^{11}$

As part of the implementation of strategies to reduce ADEs, in 2017 the 3rd Global Patient Safety Challenge was launched with the theme "Medication without harms". The goal of this challenge is to reduce serious and preventable drug-related harm by $50 \%$ over the next five years by creating health systems that are safer and more efficient in the steps of the medication process. ${ }^{12}$ It is important to highlight, therefore, the need to elaborate and adopt strategies that corroborate with the reduction of adverse events related to drugs in the Brazilian scenario, considering the greater vulnerability of middle and low income countries to these events. The understanding of the adverse event and its analysis, in a multidisciplinary way, is the best way to correct the practice; consisting of the concern with the patient's safety, the provision of instruments for care professionals to take preventive measures, approaching the event constructively. ${ }^{13}$

Nursing is the largest health workforce in Brazil, estimated around $1,500,000$ professionals working in the country. This large number of professionals then refers to the imperative of a direct relation of the category with the strategies of patient safety and prevention of errors. ${ }^{14}$

Therefore, by understanding the need to evaluate the nature and scope of these events for implementation of strategies, the purpose of this study is to identify the factors associated with Potential Drug Interactions (PDI) with High Alert Medications in an Intensive Care Unit of a Sentinel Hospital.

\section{METHODS}

Cross-sectional, retrospective study using a quantitative approach. Carried out in a university hospital, recognized as Sentinel, with medical prescriptions related to patients hospitalized at the Intensive Care Unit. This approach seeks to verify information regarding the potential drug interactions with HAM present in prescriptions of patients admitted. The study was based on the analysis of ICU patients' prescriptions for one year (January 2014 to January 2015) in order to identify the potential drug interactions related to the recurrent HAM in them through a specific guide written by authors and approved by 3 experts with expertise in the area of patient safety and pharmacovigilance. Data was collected during 6 months by a team of three researchers. Information gathered: sex, age, main diagnosis, comorbidities, date of admission to the ICU, date of discharge, transfer or death; in addition to the information related to each prescription, namely number of medications per prescription, list of prescription drugs, potential drug interactions related to HAMs. As inclusion criteria, the medical records that had 3 to 5 consecutive prescriptions related to the first days of hospitalization were analyzed; where information necessary to the collection was available. Medication prescriptions should have 
at least one HAM and be differentiated from each other. It should be noted that the HAMs belonging to the classes described in the Bulletin of the Institute for Safe Medication Practices (ISMP - "Instituto para Práticas Seguras no Uso de Medicamentos" in Portuguese language) Brazil were considered, namely: Intravenous adrenergic agonists; Intravenous, transdermal, and orally opioid analgesic; General, inhalation, and intravenous analgesic; Intravenous adrenergic antagonists; Intravenous anti-arrhythmic; Antithrombotic; Neuromuscular blockers; Intravenous radiological contrast; Oral hypoglycemic agents; Intravenous inotrope; Intravenous and subcutaneous insulin; Medications administered by epidural or intrathecal route; Medications in liposomal form and corresponding drugs; Chemotherapeutics for parenteral and oral use; Moderate-acting intravenous sedatives; Cardioplegia solutions; as well as specific medications: Concentrated injectable potassium chloride, Intravenous hypertonic sodium chloride (concentration greater than $0.9 \%$ ), Subcutaneous epinephrine, Injection of potassium phosphate, Hypertonic glucose (concentration greater than or equal to $20 \%$ ), Oral methotrexate, Injection of sodium nitrate, Intravenous oxytocin, Intravenous promethazine, Injection of magnesium sulphate, injection of vasopressin..$^{15}$

As exclusion criteria, prescriptions that were not properly dated, signed, and legible were not used.

Of the 214 charts surveyed, it was possible to select 60 , following the inclusion and exclusion criteria. Sixty-six were excluded because they did not have at least three different prescriptions; had illegible prescriptions, did not have prescriptions regarding the first week of hospitalization in the ICU or a minimum of prescriptions containing HAMs. Of the 60 charts selected, 244 drug prescriptions were verified. All available charts were analyzed to meet the inclusion criteria and possible use. Before the final data collection, a pilot test was conducted with a data collection script. However, as there was no change necessary and the number of records available was small, it was decided to use the data in the survey. For each medical record, the first prescriptions were analyzed, minimally considering the first 3 prescriptions up to the limit of the first 5 , depending on their availability and period of hospitalization of the individual. The PDIs involving at least one HAM were analyzed based on the prescriptions.

\section{Definition of Potential Drug Interactions (PDIs) and selection of drug pairs}

The PDI pairs were defined according to the indication of the Micromedex 2.0 database.${ }^{16}$ Based on the establishment of drug pairs in prescriptions, the presence or absence of drug interaction in the aforementioned database was investigated.

\section{Data processing}

The variables were analyzed using position (mean, median, minimum, and maximum) and scale statistics (standard deviation and interquartile ranges), respecting the population distribution (normal or abnormal) for each variable. In order to identify the association between the selected variables and the occurrence of
HAM-related drug interactions, there was a comparison between the average age of the patients with and without PDI, according to the $t$-student test, and the Length of hospital stay, by the Mann-Whitney test of correlations between continuous variables.

The quantity of PDI with HAM per period, length of hospital stay, number of medications prescribed, and age were described by Pearson correlation coefficients and dispersion charts.

The prevalence of drug use was expressed by absolute and relative frequencies and compared according to patients with and without PDI by the Chi-square test, as well as comorbidities, gender, and reason for hospitalization. As the number of patients who did not present PDI was very low, the number of PDIs and HAM according to medications and comorbidities were compared by the Mann-Whitney, test, then a linear model was fitted generalized with distribution Gamma and function of inverse link for the number of PDI with HAM explained by drugs, significant at the significance level of $5 \%$ according to the Mann-Whitney test. The tests considered a level of significance of $5 \%$ under two-tailed hypothesis, and the calculations were performed with the assistance of software R 3.2.2.

It should be noted that this study sought to meet all determinations present in resolution 466/12 of the National Health Council, submitted to the Research Ethics Committee and approved under opinion number 988494 .

\section{RESULTS}

\section{Patient profile}

A total of 244 medication prescriptions were selected from 60 medical records. As for sex, 25 (41.66\%) patients were female, and $35(58.33 \%)$ were male. The average age of the patients was 58.6 years old.

The main diagnoses of the patients ranged from arrhythmias, pneumonia, heart failure, syndromes, strokes, epilepsy; however, most of the patients presented oncological diseases as the main diagnosis (32-53.33\%).

The majority of patients (37-61.66\%) had preoperative or postoperative reasons for hospitalization of various surgical procedures, with a stay of less than 5 days.

It is also important to emphasize the comorbidities of the individuals who had their prescriptions analyzed. Most of them were related to Chronic Obstructive Pulmonary Disease, Systemic Arterial Hypertension, and Diabetes Mellitus. The summary of patient information is shown in Table 1.

The average number of medications received by patients in up to 5 drug prescriptions was 14 drugs.

In 244 drug prescriptions, 846 potentially HAM-related drug interactions and 112 different PDI involving HAMs were identified. 33 different high alert drugs were identified. Of these 33 drugs, 21 were present in at least one PDI.

Of the 112 types of PDI identified, some were more recurrent; namely: tramadol and ondansetron, which was identified 97 times in the prescriptions; midazolam and omeprazole, 67 times; regular 
Table 1. Characterization of patients exposed to PDI according to demographic and clinical variables, 2014-2015, Niterói, 2015

\begin{tabular}{|c|c|c|c|c|}
\hline Characteristics & & TOTAL N (\%) & $\begin{array}{c}\text { Without HAM- related } \\
\text { PDI N (\%) }\end{array}$ & $\begin{array}{c}\text { With HAM- related } \\
\text { PDI N (\%) }\end{array}$ \\
\hline \multirow[t]{2}{*}{ Gender } & MALE & 35 (58.33\%) & $1(2.85 \%)$ & 34 (97.14\%) \\
\hline & FEMALE & 25 (41.66\%) & $1(4 \%)$ & 24 (96\%) \\
\hline \multirow[t]{3}{*}{ Age in years } & $12-18$ & $1(1.66 \%)$ & $0(0 \%)$ & $1(100 \%)$ \\
\hline & $19-59$ & $30(50 \%)$ & $1(3.33 \%)$ & 29 (96.66\%) \\
\hline & $\geq 60$ & 29 (48.33\%) & $1(3.44 \%)$ & 28 (96.55\%) \\
\hline \multirow[t]{2}{*}{$\begin{array}{l}\text { Excessive polypharmacy } \\
\text { (over } 10 \text { medications) }\end{array}$} & YES & 54 (90\%) & 1 (1.85\%) & 53 (98.14\%) \\
\hline & NO & $6(10 \%)$ & $1(16.66 \%)$ & $5(83.33 \%)$ \\
\hline \multirow[t]{2}{*}{ Comorbidities } & YES & 38 (63.33\%) & $1(2.63 \%)$ & 37 (97.36\%) \\
\hline & NO & 22 (36.66\%) & 1 (4.54\%) & 21 (95.45\%) \\
\hline \multirow[t]{2}{*}{ Surgical patient } & YES & 37 (61.66\%) & $1(2.70 \%)$ & 36 (97.29\%) \\
\hline & NO & $23(38.33 \%)$ & $1(4.34 \%)$ & 22 (95.65\%) \\
\hline \multirow[t]{3}{*}{$\begin{array}{l}\text { Length of hospitaliza- } \\
\text { tion stay in days }\end{array}$} & Up to 10 & 41 (68.33\%) & $2(4.87 \%)$ & 39 (95.12\%) \\
\hline & $11-30$ & $15(25 \%)$ & $0(0 \%)$ & 15 (100\%) \\
\hline & $>30$ & $4(6.66 \%)$ & $0(0 \%)$ & 4 (100\%) \\
\hline
\end{tabular}

insulin and hydrocortisone, which occurred 54 times. Regarding PDIs among high alert drugs, the main interactions were fentanyl and midazolam, identified 74 times; as well as regular insulin and noradrenaline, observed 51 times.

\section{Statistical modeling}

Of the 60 patients in the database, only 2 did not present any cases of PDI. Therefore, the prevalence of PDI with HAM in this sample was of $0.96(96 \%)$.

It was decided to make the evaluation by the number of PDIs with HAM per period as a continuous measure. Figure 1 presents a dispersion of this quantity in relation to the logarithm of hospitalization time. There is an apparently increasing relationship if we consider patients admitted up to 45 days. Two patients were hospitalized for more than 100 days.

Figures 2 and 3 show the relationships of the amount of PDI according to the number of medications and the age of the patient. The Pearson correlation coefficient of the DI number with the number of drugs is high: 0.729 with $95 \% \mathrm{Cl}$ of [0.582; $0.829]$, so there is a correlation between the two variables. As for age, there does not seem to be any relationship. The estimated correlation in this case was -0.005 with $95 \% \mathrm{Cl}[-0.258 ; 0.249]$.

In Figure 2 we can see the existence of an association between the quantity of PDI and the amount of medication used by the patient.

Table 2, then, compares the distributions of the amount of PDI with HAM per period, considering factors such as sex, comorbidities, and medications. It is important to highlight that
Figure 1. Dispersion of hospitalization time according to the amount of PDI with HAM per period, Niterói, 2015

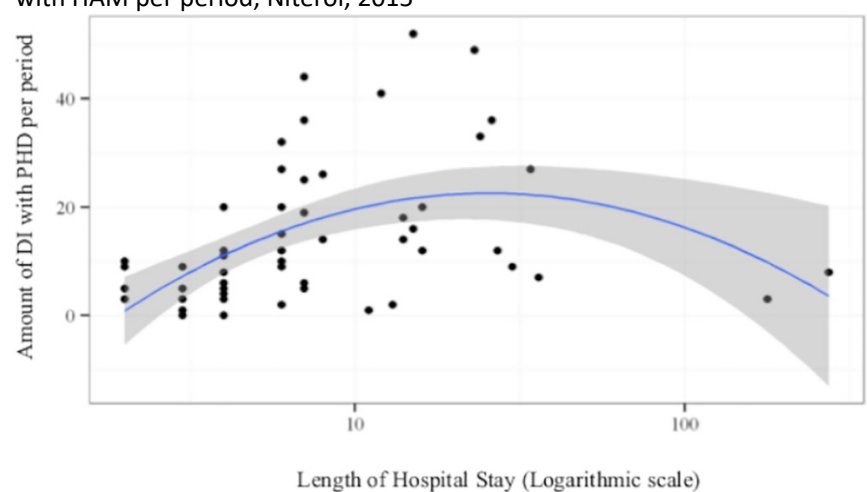

Figure 2. Dispersal of the amount of PDI with HAM per period and number of concomitant medications, Niterói, 2015

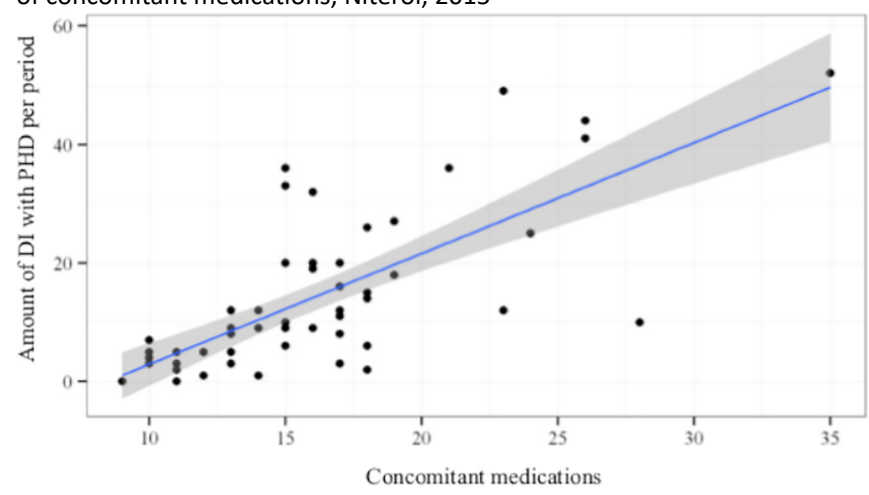


Figure 3. Dispersion of the amount of PDI with HAM by period and age (years), Niterói, 2015

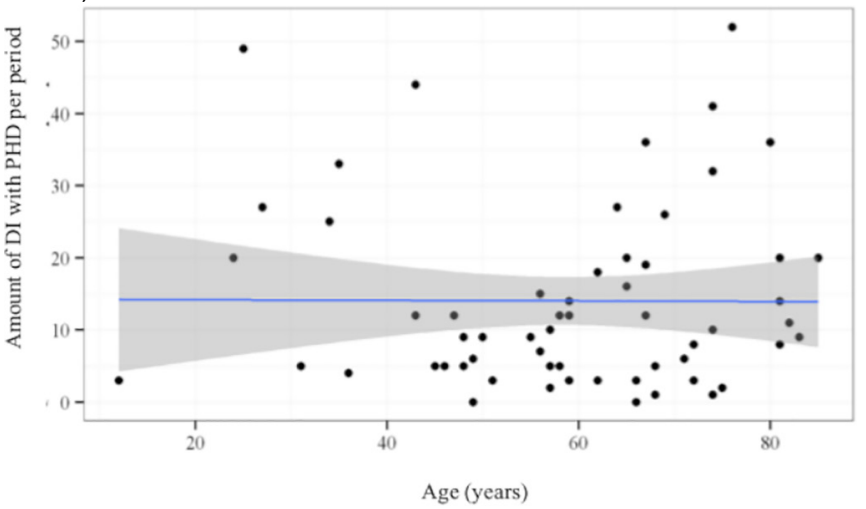

those that presented the highest propensity to cause PDI were listed in the table.

When the amount of PDI is associated with the age of the patients admitted, it is possible to note that there is apparently no correlation between these two variables, indicating that in this sample, age would not be related to PDI.

Excessive polypharmacy increases the average number of PDls from 2.3 to $12.9(p=0.012)$. And some medications seem to be more likely to cause PDI, such as Fentanyl ( $p$ value $<0.01$ ), Midazolam ( $p$ value $<0.01$ ), Noradrenaline ( $p$ value $<0.01$ ), Regular Insulin $p$ value $<0.03$ ), Amiodarone IV ( $p$ value $<0.01$ ), Tramadol ( $p$ value 0.032 ) and $K$ Phosphate ( $p$ value of 0.035 ). Administration of Midazolam, regular Insulin and Amiodarone IV were considered to be important independent drugs associated

Table 2. Comparisons of scales of the amount of PDI with HAM per period according to sex, comorbidities, and selected medications, Niterói-2015

\begin{tabular}{|c|c|c|c|c|c|c|c|c|c|c|}
\hline Variable & Factor & $\mathrm{N}$ & Min & Max & Mean & $\begin{array}{l}\text { Standard } \\
\text { deviation }\end{array}$ & Average & $\begin{array}{c}1 \text { st } \\
\text { quartile }\end{array}$ & $\begin{array}{c}3 r d \\
\text { quartile }\end{array}$ & $\mathrm{P}^{*}$ \\
\hline \multirow{2}{*}{ Sex } & Fem. & 25 & 0 & 27 & 9.72 & 7.272 & 9 & 4 & 14 & \multirow{2}{*}{0.108} \\
\hline & Male & 35 & 0 & 52 & $17.0 \mathrm{~S}$ & 14.861 & 12 & 5 & 26.5 & \\
\hline \multirow{2}{*}{ Comorbidities } & No & 22 & 0 & 44 & 11.90 & 11.169 & 8 & 5 & 17.25 & \multirow{2}{*}{0.402} \\
\hline & Yes & 38 & 0 & 52 & 15.23 & 13.552 & 11.5 & 5 & 20 & \\
\hline \multirow{2}{*}{ SAH } & No & 36 & 0 & 49 & 14.94 & 13.427 & 11 & 5 & 21.25 & \multirow{2}{*}{0.672} \\
\hline & Yes & 24 & 1 & 52 & 12.62 & 11.761 & 9.5 & 5 & 14.5 & \\
\hline \multirow{2}{*}{ DM } & No & 46 & 0 & 49 & 14.47 & 12.278 & 12 & 5 & 20 & \multirow{2}{*}{0.306} \\
\hline & Yes & 14 & 2 & 52 & 12.5 & 14.527 & 6.5 & 3.5 & 14.5 & \\
\hline \multirow{2}{*}{ COPD } & No & 52 & 0 & 49 & 13.05 & 11.703 & 9 & 5 & 19.25 & \multirow{2}{*}{0.316} \\
\hline & Yes & 8 & 2 & 52 & 20.25 & 17.831 & 13.5 & 8.25 & 33 & \\
\hline $\begin{array}{l}\text { Excessive } \\
\text { polypharmacy }\end{array}$ & No & 6 & 0 & 7 & 4 & 2.366 & 4.5 & 3.25 & 5 & 0.012 \\
\hline$(>10)$ & Yes & 54 & 0 & 52 & 15.13 & 12.938 & 12 & 5 & 20 & \\
\hline \multirow{2}{*}{ Fentanyl } & No & 37 & 0 & 20 & 7.216 & 5.287 & 5 & 3 & 10 & \multirow{2}{*}{$<0.001$} \\
\hline & Yes & 23 & 2 & 52 & 24.957 & 13.65 & 25 & 14.5 & 34.5 & \\
\hline \multirow{2}{*}{ Midazolam } & No & 40 & 0 & 70 & 7.175 & 5.088 & 5.5 & 3 & 10.25 & \multirow{2}{*}{$<0.001$} \\
\hline & Yes & 20 & 9 & 52 & 27.7 & 12.444 & 26.5 & 19 & 36 & \\
\hline \multirow{2}{*}{$\begin{array}{l}\text { Noradrena- } \\
\text { line }\end{array}$} & No & 42 & 0 & 27 & 8.714 & 6.248 & 8 & 4.25 & 12 & \multirow{2}{*}{$<0.001$} \\
\hline & Yes & 18 & 1 & 52 & 26.389 & 15.401 & 26.5 & 15 & 36 & \\
\hline \multirow{2}{*}{$\begin{array}{l}\text { Regular in- } \\
\text { sulin }\end{array}$} & No & 5 & 0 & 5 & 2.4 & 1.949 & 3 & 1 & 3 & \multirow{2}{*}{0.003} \\
\hline & Yes & 55 & 0 & 52 & 15.073 & 12.779 & 12 & 5 & 20 & \\
\hline \multirow{2}{*}{$\begin{array}{l}\text { Amiodarone } \\
\text { IV }\end{array}$} & No & 51 & 0 & 49 & 11.255 & 10.585 & 9 & 4.5 & 14 & \multirow{2}{*}{$<0.001$} \\
\hline & Yes & 9 & 8 & 52 & 29.667 & 13.105 & 32 & 20 & 36 & \\
\hline \multirow{2}{*}{ Tramadol } & No & 21 & 0 & 36 & 17.905 & 11.743 & 20 & 8 & 27 & \multirow{2}{*}{0.032} \\
\hline & Yes & 39 & 0 & 52 & 11.923 & 12.899 & 9 & 5 & 12 & \\
\hline \multirow{2}{*}{ K phosphate } & No & 48 & 0 & 52 & 12.875 & 13.114 & 9 & 4.5 & 15 & \multirow{2}{*}{0.035} \\
\hline & Yes & 12 & 4 & 36 & 18.583 & 10.326 & 17.5 & 11.5 & 26.25 & \\
\hline
\end{tabular}

* Mann-Whitney's Test 
with an increase in the number of PDIs with HAM per period at a significance level of $5 \%$.

To discover which of these drugs independently predict the amount of PDI, a generalized linear model was used, considering Gamma distribution with inverse link, indicating as explanatory variables the previously significant drugs. It is concluded that the administration of Midazolam, regular Insulin and Amiodarone IV are important independent drugs associated with an increase in the number of PDIs with HAM per period at a significance level of $5 \%$ (Table 3 ).

Table 3. Final model for Amount of PDI with HAM per period. Generalized linear model considering Gamma distribution with inverse link, Niterói, 2015

\begin{tabular}{lcccc}
\hline Coefficient & Estimate & $\begin{array}{c}\text { Standard } \\
\text { error }\end{array}$ & T value & $P$ \\
\hline Intercept & 0.413 & 0.107 & 3.847 & $<0.001$ \\
MIDAZOLAM & -0.085 & 0.014 & -6.092 & $<0.001$ \\
$\begin{array}{l}\text { REGULAR } \\
\text { INSULINE }\end{array}$ & -0.284 & 0.108 & -2.627 & $\mathbf{0 . 0 1 1}$ \\
$\begin{array}{l}\text { AMIODARONE } \\
\text { IV }\end{array}$ & -0.019 & 0.009 & -2.195 & $\mathbf{0 . 0 3 2}$ \\
& & & &
\end{tabular}

The estimates provided in Table 3 shall be interpreted as the variation in the inverse of the average of the response (Amount of PDI). That is, the average PDI per period for patients who did not use any of these 3 medications is $\frac{1}{(0.413)}=2.42$. If the patient takes midazolam, for example, the inverse of the average reduces 0.085 , i.e.: $\frac{1}{(0.413-0.085)}=3.05$, which means an increase of about $0.6 \mathrm{DI}$ per period. On the other hand, regular insulin, which has the greatest effect, becomes an average of $\frac{1}{(0.413-0.284)}=7.75$, wich means an increase of 5 PDIs per HAM per period.

Therefore, it can be understood that among the individual factors analyzed, there is a correlation between polypharmacy and the occurrence of PDI with HAM, more specifically to the use of 3 of them concomitant with other medications. Elderly patients appear to be at no greater risk of developing PDI with HAM and the length of hospital stay is directly proportional to the number of PDI with HAM.

\section{DISCUSSION}

Through the analysis of the charts, with regard to the profile of hospitalized patients, it can be seen that in the ICU of such institution there is a differentiated profile of most intensive care institutions, where patients have a demand for complex care, instability and/or severity; since the majority $(61.66 \%)$ of these came from preoperative or postoperative surgical procedures and, in a few days, was transferred to the hospital's wards.
However, it seems common that intensive care units receive severe patients, dependent on mechanical ventilation and more complex technologies. Generally, these patient profiles are preferred in these sectors.

The intensive care units are defined as a critical area for hospitalization of severe patients, who require specialized professional attention, specific materials, and the use of technologies. ${ }^{17}$

As to the demographic profile of the patients, the majority were male $(58.33 \%)$; which converges with a multicenter study where 1,124 medical records were included; of which $630(56 \%)$ were male. According to a review of the literature published in 2013 , the majority of patients hospitalized in intensive care units are male and elderly. 6,18

However, in a survey conducted in two Brazilian hospitals, the average age was 56.1 and the median age was 57 years. ${ }^{19}$ On the other hand, in a research carried out in a Brazilian tertiary care hospital, the sample $(n=573)$ presented $73 \%$ patients with age equal to or above 60 years. ${ }^{20}$ In this study, $48.32 \%$ of the patients were over 60 years of age, while the average age was 57.5 and 58.5 years, respectively, for the patients exposed and not exposed to PDI, which did not characterize a majority of elderly patients. It is believed that this profile is due to the hospitalization of many young patients before or after surgery.

In this research, age did not show any correlation with the amount of PDI in Pearson's test. In addition, when comparing the age of patients with PDI with those who did not present PDI, a statistically significant difference was not identified in the $t$-student test (p 0.934). In another study with DI in Intensive Care, drug interactions were more frequent in patients older than or equal to 60 years, but the relationship was not statistically significant $(p$ value $=0.90) .{ }^{21}$

With respect to length of hospital stay, a correlation was found between the amount of PDI per period and the length of hospital stay, indicating that this could be a predisposing factor to the PDIs. This fact is also true in other studies carried out in the intensive care. However, it would be important to adopt a careful analysis, since a larger number of drugs and consequently of PDI are usually expected in patients with longer hospitalization time. In a study comparing PDI data between 24 and 120 hours of admission to the intensive care, the average number of PDIs per patient increased from 2.9 (24 hours) to 3.3 (120 hours). ${ }^{6}$

It should be noted that the drugs strongly associated with PDI were also extensively prescribed drugs, therefore they were present in many of the PDIs; however, amiodarone was not included in this factor, since it was prescribed only to nine patients.

Fentanyl and midazolam are widely used in intensive care, so that the current literature also brings the high frequency of $\mathrm{DI}$ involving these two drugs. It was noted in researches carried out in ICU that, among the most interacting drugs, midazolam and fentanyl showed $45(14.5 \%)$ of the drug interactions identified, and of the 15 most frequent Dls, nine involved midazolam or fentanyl. ${ }^{21,22}$ 
It is also observed that of the most frequent $\mathrm{MI}$ fentanyl or midazolam were associated with eight of them. Fentanyl was also the largest interacting agent found in 36 of 54 DI pairs. ${ }^{6,19}$

It is believed that the presence of PDIs with these HAMs is due, among other factors, to their great use in intensive care. This factor, coupled with the aggravating factors of the sector and the complexity of the clientele, may increase the occurrence of errors and PDIs. In a study related to medication errors, $12.1 \%$ of the medication errors were related to HAMs, predominantly venous anesthetics (fentanyl, midazolam and propofol), corresponding to $43.3 \% .{ }^{23}$ Amiodarone, on its turn, has a known risk of increasing the QT interval. The medication has a reported drug interaction relationship with about 197 other drugs, many of them with repercussions related to prolongation of the QT interval. ${ }^{16,24}$

Insulin was also associated with PDI. In other studies, the relationship of the drug with DIs was also highlighted: of 840 pairs of Dls identified, 14 were related to insulin. Insulin was also related to the 15 main DI pairs, being the frequency of DI involving this medication of $6.67 \%$. $^{6,22}$

If we consider the relevance of insulin today, we are faced with the possible impact of errors involving these drugs. In 2012 there were about 366 million people living with diabetes mellitus worldwide, and in 2011, about 4.6 million people died from the disease. ${ }^{25}$

An important factor to be discussed is the issue of polypharmacy, which presented a strong correlation with the PDIs in this study. It is worth noting that the use of more than six medications per day increases the risk of DI by 9.8 times and the prevalence of interactions is strongly associated with the number of drugs prescribed ( $p$ 0.001). ${ }^{22,26}$

In this perspective, it is considered that patients from intensive care units may be more likely to develop drug interactions when compared to patients from other units. In addition to the risk attributed to polypharmacy, there is the risk of severity, disease, and organ failure. ${ }^{6}$

Efforts to prevent medication errors should be made, considering the great repercussion of the errors on patient safety, including therapeutic/drug reconciliation (TR). The concept emerged in 2002 in the United States and, in 2003, the Joint Commission considered TR as an indispensable activity to improve patient safety. A systematic review indicated that unintended drug discrepancies were identified in $98.2 \%$ of the patients, based on the use of drug reconciliation. ${ }^{27,28}$

The nursing team plays a fundamental role in the reduction of $A D E$, since it works uninterruptedly in care and represents, in most cases, the highest percentage of health care workers. In addition, the nursing team is the most involved in drug administration. ${ }^{29}$

It is important to emphasize in the scope of the Dls that nurses must pay attention to the period of the medical prescriptions in order to avoid that drugs that may interact and/or interfere with the effectiveness of the treatment are administered simultaneously, ensuring the proper drug administration and their intervals, redu- cing the potential adverse events associated with Dls. ${ }^{30}$

\section{CONCLUSION}

The study population was very homogeneous with respect to PDI with HAM, since only two patients were not exposed to them. Of the independent variables analyzed, namely, sex, age, comorbidities, polypharmacy, and length of hospital stay; polypharmacy and the use of some specific medications such as midazolam, regular insulin, and amiodarone IV showed a strong and significant association with the PDIs. Length of hospital stay was also associated with the presence of PDI with HAM. This research is relevant in terms of patient safety and medication use, since there are few studies focused on the drug interactions related to HAMs, especially referred to the public intensive care. Considering that Dls can configure medication errors, it is essential that the health team work with strategies to better manage the medication system, from the moment of prescription to the drug administration. This factor is especially relevant when referring to nurses, who carry out a large part of their routine work in ICU, dealing with medications. To implement strategies to reduce medication errors related to Dls, studies characterizing and establishing the profile and risk factors for these events are required. In this sense, this research finds its value. Considering also that HAMs are drugs that result in more serious events when related to errors, it is imperative to study this topic.

It is important to highlight the relevance of some medications. Some of them were more likely to cause PDI, such as Fentanyl ( $p$ value $<0.01$ ), Midazolam ( $p$ value $<0.01$ ) and regular Insulin ( $p$ value 0.03 ). This fact, in spite of the possibility to be influenced by the great use of these agents in the intensive care environment, represents their relevance when it comes to errors related to the medication system. This is also true when listening to current literature. The errors and DAEs related to these drugs are frequent in several studies carried out in ICU or ITU. Due to the pharmacodynamics of these drugs, the repercussions may be even more serious, considering the patient hospitalized in ICU or ITU; usually polymedicated, elderly, presenting comorbidities, and with possibility of inefficiency in the processes of metabolization and excretion of medications. In this way some vigilance must be established in order to avoid unnecessary DI or when the joint administration of certain inter-agents is indispensable; one must possess the competences to handle this administration in a more adequate way with the lowest possible risk for the patient.

Regarding the limitations of the study, the number of individuals was small and the study was carried out in only one unit, which makes it difficult to generalize the results. It is believed that further studies are needed, with a larger number of participants, in order to give greater power to the analysis. It should also be noted that some drugs were not identified in the software used to carry out the study, so the possible Dls involving them were not considered. This fact may then underestimate the prevalence of 
PDIs. Regarding method and data analysis, it was intended to establish the risk factors for DIs with HAM; however, since the number of patients that did not present DI was very low (only 2), the number of Dls with HAM were compared according to medications and comorbidities by the Mann-Whitney test.

\section{REFERENCES}

1. Slawomirski L, Auraaen A, Klazinga N. The economics of patient safety: Strengthening a value-based approach to reducing patient harm at national level. OECD [Internet]. 2017 Mar; [cited 2018 Sep 27]. Available from: https://www.bundesgesundheitsministerium.de/fileadmin/ Dateien/3_Downloads/P/Patientensicherheit/The_Economics_of_ patient_safety_Web.pdf

2. Tramontina MY, Ferreira MB, Astro MS, Heineck I. Comorbidities, potentially dangerous and low therapeutic index medications: factors linked to emergency visits. Ciênc Saúde Coletiva [Internet]. 2018; [cited 2018 Sep 23]; 23(5):1471-82. Available from: http://www.scielo. br/pdf/csc/v23n5/1413-8123-csc-23-05-1471.pdf. DOI: 10.1590/141381232018235.07512016

3. Alsaidan J, Portlock J, Aljadhey HS, Shebl NA, Franklin BD. Systematic review of the safety of medication use in inpatient, outpatient and primary care settings in the Gulf Cooperation Council countries. Saudi Pharm J [Internet]. 2018 Mar; [cited 2019Mar8]; 26(7):977-1011. Available from: https://www.ncbi.nlm.nih.gov/pubmed/30416356

4. Committee of Experts on Management of Safety and Quality in Health Care (SP-SQS). Expert Group on Safe Medication Practices. Glossary of terms related to patient and medication safety [Internet]; 2005. Available from: https://www.who.int/patientsafety/highlights/ COE_patient_and_medication_safety_gl.pdf

5. Ismail M, Noor S, Harram U, Haq I, Haider I, Khadim F, et al. Potential drug-drug interactions in outpatient department of a tertiary care hospital in Pakistan: a cross-sectional study. BMC Health Serv Res [Internet]. 2018 Oct; [cited 2019 Mar 8]; 18(1):762. Available from: https://www.ncbi.nlm.nih.gov/pubmed/30314487. DOI: 10.1186/ s12913-018-3579-7

6. Carvalho REFL, Reis AMM, Faria LMP, Zago KSA, Cassiani SHB. Prevalência de interações medicamentosas em unidades de terapia intensiva no Brasil. Acta Paul Enferm [Internet]. 2013; [cited 2016 Jul 20]; 26(2):150-7. Available from: http://www.scielo.br/pdf/ ape/v26n2/v26n2a08.pdf. DOI: http://dx.doi.org/10.1590/S010321002013000400001

7. Ministério da Saúde (BR). Agência Nacional de Vigilância Sanitária. Sistema Nacional de Notificações para a Vigilância Sanitária: Notificações em vigilância Sanitária. Brasília (DF): Ministério da Saúde; 2016. [cited $2018 \mathrm{Jul}$ 20]. Available from: http://portal.anvisa.gov.br/ notivisa.

8. Sousa LAO, Fonteles MMF, Monteiro MP, Mengue SS, Bertoldi AD, Pizzol TS, et al. Prevalência e características dos eventos adversos a medicamentos no Brasil. Cad Saúde Pública [Internet]. 2018; [cited 2018 Sep 23]; 34(4):e00040017. Available from: http://cadernos. ensp.fiocruz.br/csp/artigo/402/prevalncia-e-caractersticas-doseventos- adversos-a-medicamentos-no-brasil. DOI: http://dx.doi. org/10.1590/0102-311X00040017

9. World Health Organization (WHO). Medication Errors: Technical Series on Safer Primary Care. 2016 [Internet]. [cited 2019 Mar 8]. Available from: https://apps.who.int/iris/bitstream/hand le/10665/252274/9789241511643-eng.pdf;jsessionid=C187C31196 C090D0C10DF40319FF9208?sequence $=1$

10. Instituto para Práticas Seguras no Uso dos Medicamentos (BR). Medicamentos potencialmente perigosos de uso hospitalar e ambulatorial - listas atualizadas 2015. Belo Horizonte (MG); 2015. [cited 2016 Sep 20]. Available from: https://www.ismp-brasil.org/site/ wp-content/uploads/2015/12/V4N3.pdf.

11. Nascimento LC. Custos decorrentes de eventos adversos a medicamento em pacientes hospitalizados [dissertação]. Goiânia (GO): Universidade Federal de Goiás; 2018.
12. World Health Organization (WHO). Global Patient Safety Challenge. Medication Without Harm. 2017 [cited 2018 Sep 25]. Available from: http://apps.who.int/iris/bitstream/handle/10665/255263/WHO-HISSDS-2017.6-eng.pdf?sequence $=1$

13. Pena MM, Melleiro MM. O método de análise de causa raiz para a investigação de eventos adversos. Rev Enferm UFPE [Internet] 2017 Dec; [cited 2018 Sep 25]; 11(Supl. 12):5297-304. Available from: http://periodicos.ufpe.br/revistas/revistaenfermagem/article/ download/25092/25482. DOI: https://doi.org/10.5205/1981-8963v11i12a25092p5297-5304-2017

14. Duarte SCM, Stipp MAC, Silva MM, Oliveira FT. Eventos adversos e segurança na assistência de enfermagem. Rev Bras Enferm [Internet]. $2015 \mathrm{Jan} / F e b ;$ [cited 2018 Mar 8]; 68(1):144-54. Available from: http:// www.scielo.br/pdf/reben/v68n1/0034-7167-reben-68-01-0144.pdf. DOI: http://dx.doi.org/10.1590/0034-7167.2015680120p

15. Instituto para Práticas Seguras no Uso dos Medicamentos (BR). Medicamentos potencialmente perigosos de uso hospitalar e ambulatorial. Listas atualizadas 2015. Belo Horizonte: ISMP; 2015 [cited 2019 Dec 17]. Available from: http://www.ismp-brasil.org/site/ wp-content/uploads/2015/12/V4N3.pdf

16. Micromedex Solutions. Interações medicamentosas [Internet]. 2018 [cited 2018 Oct 2]. Available from: https://www-micromedexsolutionscom.ez24.periodicos.capes.gov.br/micromedex2/librarian

17. Ministério da Saúde (BR). Agência Nacional de Vigilância Sanitária Resolução-RDC № 7, 24 de fevereiro de 2010. Dispõe sobre os requisitos mínimos para funcionamento de Unidades de Terapia Intensiva e dá outras providências. Brasília (DF): Ministério da Saúde ; 2010. [cited 2017 Jul 20]. Available from: http://bvsms.saude.gov.br/ bvs/saudelegis/anvisa/2010/res0007_24_02_2010.html

18. Moreira ET, Nunes TF, Santos ES, Calles ACN. Perfil e gravidade dos pacientes admitidos em unidades de terapia intensiva: uma revisão de literatura. Cad Grad [Internet]. 2013 May; [cited 2018 Sep 24]; 1(2):45-52. Available from:https://periodicos.set.edu.br/index.php/fitsbiosaude/article/ view/588/364

19. Vieira LB, Reis AMM, Carvalho REFL, Faria LMP, Cassiani SHB. Interações Medicamentosas Potenciais em Pacientes de Unidades de Terapia Intensiva. Rev Ciênc Farm Básica Apl [Internet]. 2012; [cited 2018 May 18]; 33(3):401-8. Available from: http://serv-bib.fcfar.unesp.br/seer/index. php/Cien_Farm/article/viewFile/2009/1260

20. Albuquerque JM, Silva RFA, Souza RFF. Epidemiological profile and monitoring after discharge of patients hospitalized at an intensive care unit. Cogitare Enferm [Internet]. 2017; [cited 2019 Jan 30]; 22(3):e50609. Available from: http://docs.bvsalud.org/biblioref/2017/12/876102/50609212517-1-pb.pdf. DOI: http://dx.doi.org/10.5380.

21. Lima REF, Cassiani SHB. Interações medicamentosas potenciais em pacientes de unidade de terapia intensiva de um hospital universitário. Rev Lat Am Enferm [Internet]. 2009 Mar/Apr; [cited 2018 Oct 17]; 17(2):222-7. Available from: http://www.scielo.br/scielo.php?pid=s010411692009000200013\&script=sci_arttext\&tlng=pt. DOI: http://dx.doi. org/10.1590/S0104-11692009000200013

22. Caribé RA, Chaves GR, Pocognoni JD, Souza IA. Potenciales interacciones medicamentosas en pacientes con sepsisinternados en la unidad de terapia intensiva. Farm Hosp [Internet].2013; [cited 2017 Jul 20]; 37(5):3837. Available from: http://scielo.isciii.es/pdf/fh/v37n5/07original05.pdf. DOI: 10.7399/FH.2013.37.5.534

23. Bohomol E. Erros de medicação: estudo descritivo das classes de medicamentos de alta vigilância. Esc Anna Nery [Internet]. 2014 Apr/ Jun; [cited 2018 May 20]; 18(2):311-6. Available from: http://www.scielo. br/pdf/ean/v18n2/1414-8145-ean-18-02-0311.pdf. DOI: 10.5935/14148145.20140045

24. Martins JM, Figueiredo TP, Costa SC, Reis AMM. Medicamentos que podem induzir prolongamento do intervalo QT utilizados por idosos em domicílio. Rev Ciênc Farm Básica Apl [Internet]. 2015; [cited 2018 Jul 5]; 36(2):297-305. Available from: http://seer.fcfar.unesp.br/rcfba/index.php/ rcfba/article/view/245

25. International Diabetes Federation. Diabetes atlas. 6th ed [Internet]. 2014 [cited 2017 Sep 25]. Available from: http://www.idf.org/sites/default/files/ Atlas-poster-2014_EN.pdf 
26. Hammes JA, Pfuetzenreiter F, Silveira F, Koenig A, Westphal GA. Prevalência de potenciais interações medicamentosas droga-droga em unidades de terapia intensiva. Rev Bras Ter Intensiva [Internet]. 2008 Oct/ Dec; [cited 2018 Sep 20]; 20(9):349-54. Available from: http://www.scielo. $\mathrm{br} / \mathrm{pdf} / \mathrm{rbti} / \mathrm{v20n} 4 / \mathrm{v} 20 \mathrm{n} 4 \mathrm{a06} . \mathrm{pdf}$

27. Afonso R. Reconciliação de Terapêutica. Rev Clin Hosp Prof Dr Fernando Fonseca [Internet]. 2015; [cited 2019 Mar 8]; 3(1):35-6. Available from: https://repositorio.hff.min-saude.pt/bitstream/10400.10/1506/1/14\%20 Reconciliação\%20de\%20Terapêutica.pdf

28. Lehnbom EC, Stewart MJ, Manias E, Westbrook JI. Impact of medication reconciliation and review on clinical outcomes. Ann Pharmacother [Internet]. 2014 Oct; [cited 2016 Jan 17]; 48(10):1298-312. Available from:https://www. ncbi.nlm.nih.gov/pubmed/25048794. DOI: 10.1177/1060028014543485
29. Oliveira JKA, Llapa-Rodriguez EO, Lobo IMF, Lôbo LSS, Godoy $\mathrm{S}$, Silva GG. Patient safety in nursing care during medication administration. Rev Lat Am Enferm [Internet]. 2018; [cited 2019 Mar 8] 26:e3017. Available from: http://www.scielo.br/scielo.php?pid=S010411692018000100333\&script=sci_arttext\&tIng=en. DOI: http://dx.doi. org/10.1590/1518-8345.2350.3017

30. Antunes JFS, Okuno MFP, Lopes MCBT, Campanharo CRV, Batista REA. Interação medicamentosa em idosos internados no serviço de emergência de um hospital universitário. REME Rev Min Enferm [Internet]. 2015 Oct/Dec; [cited 2018 Oct 5]; 19(4):907-12. Available from: http://www.reme.org.br/artigo/detalhes/1059. DOI: 10.5935/14152762.20150070 